\title{
Physico-chemical quality and microbial safety evaluation of ready-to-eat fresh- cut watermelon and pineapple sold in Imus, Cavite, Philippines
}

\author{
Piano, A.M.P. and ${ }^{*}$ Castillo-Israel, K.A.T. \\ Institute of Food Science and Technology, College of Agriculture and Food Science, University of the \\ Philippines Los Banos, College, Laguna 4031
}

\author{
Article history: \\ Received: 29 March 2019 \\ Received in revised form: 9 \\ May 2019 \\ Accepted: 11 May 2019 \\ Available Online: 24 May \\ 2019
}

Keywords:

Watermelon,

Pineapple,

Fresh-cuts,

Wet market,

Supermarket,

E. coli

DOI:

https://doi.org/10.26656/fr.2017.3(6).139

\begin{abstract}
The study aimed to evaluate the physico-chemical quality and microbial safety of ready-to -eat fresh-cut watermelon and pineapple sold in selected wet markets and supermarkets in Imus, Cavite. These two fruits are the top-selling fresh-cut fruits in the area based on a prior survey conducted. Higher water soaking scores were obtained from fresh-cut fruits in wet markets while lower visual quality scores were obtained from wet market samples compared with those from supermarkets. Comparing fresh-cuts from whole fruits, lower vitamin $\mathrm{C}$ content was observed on fresh-cut samples than whole fruit samples. For Total plate count of fresh-cut watermelons, no sample exceeded the maximum tolerance level $\left(10^{7} \mathrm{CFU} / \mathrm{mL}\right)$ for the production day for the supermarket samples while 3 out of 6 samples from the wet markets had exceeding levels. For pineapple, the number of samples which exceeded the tolerance levels were 4 out of 6 from supermarkets and 3 out of 6 from wet markets. For yeast and molds count, (maximum tolerance level is $10^{4}$ ), all watermelon samples did not have exceeding levels while 5 out of 6 samples both from supermarkets and wet markets had exceeding levels. For Total coliforms, maximum tolerance is $10^{2}$. All watermelon samples exceeded this level. For pineapple, all from supermarkets and 3 out of 6 samples from wet markets exceeded the levels. All fresh-cut pineapple and watermelon samples were negative for Escherichia coli. For watermelon, 2 samples each from supermarkets and wet markets were positive for Salmonella while for pineapple, 1 sample from the supermarket and 3 from wet markets turned out positive.
\end{abstract}

\section{Introduction}

Fruits provide an inexpensive and abundant source of energy, vitamins and minerals and functional nutrients (James and Kuipers, 2003). When they are in the fresh state, their nutritional value is highest since the nutritional components such as vitamins and phytochemicals which are prone to oxidation and destruction by heat are still in their native state. Also, most fruits are only edible for a very short time due to their high perishability caused by biochemical and microbial deterioration. Fresh-cut fruits have become popular in recent years. A per capita volume growth from 2009-2014 for fresh-cut fruits in the Asia Pacific was about 18\% (Kocheri, 2015). The International Freshcut Produce Association (IFPA) defines fresh-cut products like fruits or vegetables that have been trimmed and/or peeled and/or cut into $100 \%$ usable product that is bagged or pre-packaged to offer consumers high nutrition, convenience, and flavor while maintaining its freshness (Lamikanra, 2002).
In particular, freshness, nutritive value, low priced, and ready-to-eat are some reasons why fresh-cut fruits attract consumers. Because of this, different mixes and wide assortment of minimally processed fruits have been developed to meet consumer's demand for convenient and healthy product (Ahvenainen, 1996). Additional value to fresh-cut fruits in terms of convenience and time saving are being developed thru minimal processing, although several hurdles are encountered due to the challenge in preserving its freshness for prolonged periods. Fresh cut fruits and vegetables are characterized by a shorter shelf life than their whole counterparts. This is because of increased respiration rate and ethylene production and higher susceptibility to microbial spoilage, which is stimulated by cutting results in wounding of the tissue (Chien et al., 2007). Among many foodborne pathogens that were traced back to fresh vegetables and fruits, Salmonella is most linked to the foodborne disease outbreaks (Brody et al., 2011).

Fresh-cut produce is sold in open-air markets and food stands in many Asian countries and is increasingly 
being sold in supermarkets (Sa-Nguanpuag et al., 2007). The market for fresh-cut products in Japan and the Republic of Korea has shown a steady growth trend since the late 1980s and 1990s respectively (Kim, 2007). While the food service industry for school meals and restaurants is the main user of fresh-cut products in these countries, demand for them has grown in retail markets. However, with increasing demand for fresh-cuts at the retail level, the fresh-cut industries in Japan and the Republic of Korea are facing challenges to extend shelflife and enhance food safety (James and Ngarmsak, 2010).

Although many forms of food processing are designed to minimize food safety risks, rapid growth in the food processing industry can contribute to foodborne illness outbreaks (Woteki and Kineman, 2003). Because of this, it is important to determine the microbial load and the physico-chemical properties of ready to eat fresh -cut fruits to have primary information on the safety and quality of these food forms. This study also attempts to compare the physico-chemical changes in the whole fruits after they are converted to fresh-cuts, as well as the quality and safety of fresh-cuts sold in two types of markets: wet market and supermarket. This study particularly studied fresh-cut pineapple and watermelon, the two highest selling fresh cuts in Imus, Cavite, which represents a highly urbanized town in South Luzon, Philippines.

\section{Materials and methods}

\subsection{Sampling}

Samples of fresh-cut pineapple and watermelon were obtained from 2 wet markets and 2 supermarkets in Imus, Cavite. The two largest wet markets and supermarkets were chosen. Whole fruits(control) of pineapple and watermelon were also obtained from the same stores. For the physico-chemical analyses, 2 samples were obtained from each store. For the microbial analyses, 3 fresh-cut samples were obtained from each store. The fruits were placed in an iced container then brought to the Institute of Food Science and Technology, UP Los Baños for physico-chemical and microbiological analyses. Seedless fruit samples were homogenized with a waring blender prior to analyses.

\subsection{Physico-chemical analyses}

\subsection{1 $\mathrm{pH}$}

Calibrated $\mathrm{pH}$ meter (Eutech) was used for the measurement of $\mathrm{pH}$ of the samples.

\subsubsection{Total soluble solids}

Total soluble solids were determined using a handheld refractometer (Atago).

\subsubsection{Titratable acidity}

A total of $10 \mathrm{~mL}$ of the sample was placed in an Erlenmeyer flask containing $90 \mathrm{~mL}$ of distilled water with neutral $\mathrm{pH}$. The sample was then titrated with standardized $0.1 \mathrm{~N} \mathrm{NaOH}$ until faint pink endpoint. Phenolphthalein indicator was used in the analysis. TA was calculated as follows:

$$
\% \text { acid }\left(\frac{\mathrm{wt}}{\mathrm{vol}}\right)=\frac{\mathrm{N} \times \mathrm{V}_{1} \times \text { eq wt }}{\mathrm{V}_{2} \times 1000} \times 100
$$

Where $\mathrm{N}=$ normality of titrant $(\mathrm{mEq} / \mathrm{mL}) ; \mathrm{V}_{1}=$ volume of titrant $(\mathrm{mL}) ; \mathrm{Eq}$ wt $=$ equivalent weight of predominant acid $(\mathrm{mg} / \mathrm{mEq}) ; \mathrm{V}_{2}=$ volume of sample $(\mathrm{mL}) ;$ and $1000=$ factor relating to $\mathrm{mg}$ to grams $(\mathrm{mg} / \mathrm{g})$

\subsubsection{Vitamin $C$ analysis}

\subsubsection{Standardization of indophenol dye solution}

An aliquot $(1 \mathrm{~mL})$ of ascorbic acid solution $(25 \mathrm{mg}$ chemically pure ascorbic acid in $100 \mathrm{~mL} 0.4 \%$ oxalic acid solution) was placed in $50 \mathrm{~mL}$ Erlenmeyer flask. The sample was then titrated using $0.04 \%$ indophenols dye solution endpoint. Dye factor was computed using the formula below:

$$
\begin{aligned}
& * \text { dye factor }(\mathrm{df})=\frac{1 \mathrm{~mL} \times \frac{\mathrm{mg} \text { ascorbic acid }}{100 \mathrm{~mL} \text { oxalic acid }}}{\text { volume used indopehonol dye solution }} \\
& \text { 2.2.4.2 Analysis of the sample }
\end{aligned}
$$

A total of $2 \mathrm{~mL}$ of the sample and $8 \mathrm{~mL} 0.4 \%$ oxalic acid solution were placed in $50 \mathrm{~mL}$ Erlenmeyer flask. The solution was then titrated using $0.04 \%$ indophenol dye solution to the pink endpoint. The Vitamin $\mathrm{C}$ of the samples were computed with the formula below:

\section{$\frac{\text { mg ascorbic acid }}{100 \text { g sample }}=\frac{\mathrm{df} \times \mathrm{V}_{\text {indophenol dye }} \times \text { total volume extract } \times 100}{\mathrm{~V}_{\text {sample }} \times \text { wt. of sample blended }}$ \\ 2.2.5 Color}

Color values $\left(\mathrm{L}^{*}, \mathrm{a}^{*}, \mathrm{~b}^{*}\right)$ were monitored using Konika Minolta Color Reader CR-10.

\subsubsection{Visual Quality Rating (VRQ)}

The overall acceptability of the sample was measured using VQR. The following scores with corresponding description applied: 9,8 (excellent, field fresh); 7,6 (good with minor defects); 5,4 (fair with moderate defects); 3 (poor with serious defects/ limit of saleability); 2 (limit of edibility); 1 (non-edible under usual conditions). This VQR scale is established and is being used by the Postharvest Horticulture Training and Research Center (PHTRC), UP Los Banos. 


\subsubsection{Water Soaking Index (WSI)}

The degree of water soaking was rated as: 1 (none: 0\%); 2 (slight: 5-10\%); 3 (moderate: 11-15\%); 4 (above moderate: $16-30 \%$ ); 5 (severe: $>30 \%$ of fruit surface). This water soaking scale is established and is being used by the Postharvest Horticulture Training and Research Center (PHTRC), UP Los Banos.

\subsection{Microbiological analyses}

\subsubsection{Preparation of the sample}

Watermelon and pineapple samples were collected and transported in an ice box. Samples were kept stored at $4{ }^{\circ} \mathrm{C}$ until the analyses begin. The fruit sample was weighed $25 \mathrm{~g}$ aseptically into a sterile autoclavable bag. $0.1 \%$ peptone water was added to the plastic bag and homogenized for 2 mins. Decimal dilutions of up to $10^{-5}$ of the samples were prepared.

\subsubsection{Total plate count}

An aliquot $(1 \mathrm{~mL})$ of the test sample with appropriate dilutions was pipetted into sterile petri dish. Molten, cooled Plate Count Agar (PCA) was added followed by gently mixing to distribute the sample dilution throughout the agar. Hardened plates were incubated for $48 \pm 3 \mathrm{hrs}$ at $35 \pm 0.5^{\circ} \mathrm{C}$ in an aerobic atmosphere.

\subsubsection{Enumeration of total coliforms}

An aliquot $(1 \mathrm{~mL})$ of the fruit sample was transferred to a petri dish. Fifteen $\mathrm{mL}$ of molten Violet red bile agar (VRBA) was poured on the aliquot. Inverted plates were incubated at $35^{\circ} \mathrm{C}$ for $18-24 \mathrm{hrs}$.

\subsubsection{Test for Escherichia coli}

Samples were forwarded to UPLB BIOTECH for the detection of Escherichia coli using DASTM kit, a PCRbased detection method for E. coli.

\subsubsection{Detection of Salmonella}

Fruit sample of $25 \mathrm{~g}$ was weighed and transferred to $225 \mathrm{~mL} 0.5 \%$ lactose broth then incubated at $35^{\circ} \mathrm{C}$ for 24 hrs. An aliquot $(1 \mathrm{~mL})$ of the pre-enriched sample was transferred to $10 \mathrm{~mL}$ selenite cystine broth. The cultures were incubated at $35^{\circ} \mathrm{C}$ for $24 \mathrm{hrs}$. A loopful of the culture from the enrichment media was streaked to Brilliant Green Agar (BGA) incubated at $35^{\circ} \mathrm{C}$ for 24 hrs. Two typical or suspicious Salmonella colonies from the medium were stab-streak to Triple Sugar Iron (TSI) agar using a needle. If there were no typical or suspicious looking colonies, or the plates do not have any growth, the plates were incubated for additional 24 hrs at $35^{\circ} \mathrm{C}$.

\subsubsection{Test for yeasts and molds}

An aliquot $(1 \mathrm{~mL})$ was pour plated with Potato Dextrose Agar (PDA) with $14 \mathrm{~mL}$ of $10 \%$ tartaric acid added for every liter. The plates were incubated at $30^{\circ} \mathrm{C}$ for 5 days.

\section{Results and discussion}

3.1 Physico-chemical analyses of fresh-cut watermelon and fresh-cut pineapple

A total of 24 packs of fresh-cut watermelons and fresh-cut pineapples from two wet markets and two supermarkets in Imus, Cavite were analyzed for physicochemical quality in terms of water soaking index, visual quality rating, color $\left(\mathrm{L}^{*}, \mathrm{a}^{*}, \mathrm{~b}^{*}\right)$, vitamin $\mathrm{C}$ content, total titratable acidity, $\mathrm{pH}$, and total soluble solids. Physicochemical quality of whole watermelons and pineapples were also analyzed to serve as the control for the analyses. Results of the physico-chemical analyses are shown in Table 1 for watermelon and Table 2 for pineapple.

\subsubsection{Water soaking and visual quality rating}

The index of water soaking of fresh cut watermelon from supermarket 1 and both wet markets had above moderate to severe water soaking while fresh cut watermelon from supermarket 2 was not observed to have water soaking. As for fresh cut pineapples, samples have $0 \%$ water soaking index except for fresh cut pineapple from wet market 2. Generally, fresh-cuts from supermarkets had lesser water soaking than those from the wet market. Comparing the fresh-cut fruits to its corresponding whole fruits, water soaking on whole watermelons and whole pineapples were not observed. Water soaking has been most commonly associated with spoilage of cut cantaloupe, honeydew, and watermelon especially under abusive storage temperature $\left(>4^{\circ} \mathrm{C}\right)$ (Ukuku and Fett, 2002). The difference in the water soaking of fresh-cuts between those from the supermarkets and wet markets is due to storage temperature. Chilling temperature in chiller displays are used in supermarkets while wet markets store the samples at ambient temperature, usually in the open air. Tissue softening is a very serious problem with fresh-cut fruit products and can limit shelf-life. Fresh-cut fruit firmness is an important quality attribute that can be affected by cell softening enzymes present in the fruit tissue and by decreased turgor due to water loss (Varoquaux and Maxollier, 1990). The visual quality of fresh-cut watermelon and fresh cut pineapples was rated from 1 to 9. Results showed that visual quality of freshcut watermelons was lower than those of whole watermelons. Fresh cut watermelon samples from wet market 2 had a visual rating of 1 (non-edible under usual 
Table 1. Physico-chemical properties of ready-to-eat fresh-cut watermelons and whole watermelons obtained from different supermarkets and wet markets in Imus, Cavite

\begin{tabular}{|c|c|c|c|c|c|c|c|c|c|c|}
\hline \multicolumn{2}{|c|}{ *Code } & Water soaking & VQR & $\mathrm{L}^{*}$ & $a^{*}$ & $\mathrm{~b}^{*}$ & Vitamin C (mg/100 g) & Titratable acidity (\%) & $\mathrm{pH}$ & TSS ( ${ }^{\circ}$ brix $)$ \\
\hline \multirow{4}{*}{ Sample } & SM1 & 4 & 6 & $37.16^{\mathrm{a}}$ & $25.11^{\mathrm{a}}$ & $15.83^{\mathrm{a}}$ & $7.30^{\mathrm{a}}$ & $0.053^{\text {af }}$ & $5.79^{\mathrm{a}}$ & $6.4^{\mathrm{a}}$ \\
\hline & SM2 & 1 & 9 & $31.99^{\mathrm{a}}$ & $24.92^{\mathrm{a}}$ & $16.21^{\mathrm{a}}$ & $7.59^{\mathrm{a}}$ & $0.057^{\mathrm{ab}}$ & $5.78^{\mathrm{a}}$ & $8.2^{\mathrm{b}}$ \\
\hline & WM1 & 4 & 7 & $37.25^{\mathrm{a}}$ & $21.42^{\mathrm{ab}}$ & $10.13^{b}$ & $6.99^{\mathrm{a}}$ & $0.081^{\mathrm{c}}$ & $5.80^{\mathrm{a}}$ & $7.5^{\mathrm{ab}}$ \\
\hline & WM2 & 5 & 1 & $35.95^{\mathrm{a}}$ & $15.73^{b}$ & $11.37^{\mathrm{b}}$ & $4.04^{b}$ & $0.13^{\mathrm{d}}$ & $5.19^{b}$ & $6.3^{\mathrm{ac}}$ \\
\hline \multirow{4}{*}{ Control } & SM1 & 1 & 9 & $32.45^{\mathrm{a}}$ & $24.39^{\mathrm{a}}$ & $15.39^{\mathrm{a}}$ & $10.38^{\mathrm{c}}$ & $0.073^{b c}$ & $5.65^{\mathrm{a}}$ & $6.8^{\mathrm{ab}}$ \\
\hline & SM2 & 1 & 9 & $36.45^{\mathrm{a}}$ & $24.79^{\mathrm{a}}$ & $18.11^{\mathrm{a}}$ & $9.84^{\mathrm{c}}$ & $0.063^{\mathrm{acf}}$ & $6.00^{\mathrm{a}}$ & $8.7^{\mathrm{b}}$ \\
\hline & WM1 & 1 & 9 & $31.33^{\mathrm{a}}$ & $28.16^{\mathrm{a}}$ & $16.58^{\mathrm{a}}$ & $9.41^{\mathrm{c}}$ & $0.074^{\mathrm{bc}}$ & $6.04^{\mathrm{a}}$ & $9^{b}$ \\
\hline & WM2 & 1 & 9 & $31.84^{\mathrm{a}}$ & $26.21^{\mathrm{a}}$ & $14.94^{\mathrm{a}}$ & $9.57^{\mathrm{c}}$ & $0.061^{\mathrm{abf}}$ & $5.81^{\mathrm{a}}$ & $8^{\text {bd }}$ \\
\hline
\end{tabular}

Table 2. Physico-chemical properties of ready-to-eat fresh-cut pineapples and whole pineapples obtained from different supermarkets and wet markets in Imus, Cavite

\begin{tabular}{|c|c|c|c|c|c|c|c|c|c|c|}
\hline \multicolumn{2}{|c|}{ *Code } & Water soaking & VQR & $\mathrm{L}^{*}$ & $a^{*}$ & $\mathrm{~b}^{*}$ & Vitamin C (mg/100 g) & Titratable acidity (\%) & $\mathrm{pH}$ & TSS ( ${ }^{\circ}$ brix) \\
\hline \multirow[t]{4}{*}{ Sample } & SM1 & 1 & 7 & $72.32^{\mathrm{a}}$ & $4.017^{\mathrm{a}}$ & $36.61^{\mathrm{a}}$ & $7.05^{\mathrm{a}}$ & $0.41^{\mathrm{a}}$ & $3.67^{\mathrm{a}}$ & $12.9^{\mathrm{a}}$ \\
\hline & SM2 & 1 & 8 & $71.63^{\mathrm{a}}$ & $0.063^{\mathrm{b}}$ & $28.53^{\mathrm{b}}$ & $7.05^{\mathrm{a}}$ & $0.34^{\mathrm{a}}$ & $3.79^{\mathrm{a}}$ & $13.5^{\mathrm{a}}$ \\
\hline & WM1 & 1 & 8 & $71.50^{\mathrm{a}}$ & $0.36^{\mathrm{b}}$ & $29.80^{\mathrm{b}}$ & $4.90^{\mathrm{b}}$ & $0.071^{\mathrm{a}}$ & $4.05^{\mathrm{a}}$ & $14.6^{\mathrm{a}}$ \\
\hline & WM2 & 2 & 8 & $64.66^{\mathrm{a}}$ & $-0.23^{b}$ & $31.46^{\mathrm{ab}}$ & $5.79^{\mathrm{b}}$ & $0.13^{\mathrm{a}}$ & $4.05^{\mathrm{a}}$ & $15.6^{\mathrm{a}}$ \\
\hline \multirow[t]{4}{*}{ Control } & SM1 & 1 & 7 & $72.65^{\mathrm{a}}$ & $-0.84^{\mathrm{b}}$ & $30.87^{\mathrm{b}}$ & $10.76^{\mathrm{cd}}$ & $0.27^{\mathrm{a}}$ & $3.97^{\mathrm{a}}$ & $12.5^{\mathrm{a}}$ \\
\hline & SM2 & 1 & 8 & $73.85^{\mathrm{a}}$ & $-1.65^{\mathrm{b}}$ & $21.06^{\mathrm{c}}$ & $11.40^{\mathrm{c}}$ & $0.25^{\mathrm{a}}$ & $3.92^{\mathrm{a}}$ & $13.6^{\mathrm{a}}$ \\
\hline & WM1 & 1 & 8 & $64.70^{\mathrm{a}}$ & $-0.79^{b}$ & $31.44^{\mathrm{ab}}$ & $9.05^{\mathrm{d}}$ & $0.29^{\mathrm{a}}$ & $3.92^{\mathrm{a}}$ & $14.3^{\mathrm{a}}$ \\
\hline & WM2 & 1 & 8 & $67.90^{\mathrm{a}}$ & $-0.62^{b}$ & $31.49^{\mathrm{ab}}$ & $9.99^{\mathrm{cd}}$ & $0.19^{\mathrm{a}}$ & $3.82^{\mathrm{a}}$ & $12.2^{\mathrm{a}}$ \\
\hline
\end{tabular}

Means bearing the same superscript within the same column are not significantly different ( $\mathrm{p}>0.05)$.

*Code: SM1 - Supermarket 1; SM2- Supermarket 2; WM1 - Wet market 1; and WM2 - Wet market 2.

conditions) and noted to have foul smell. For pineapple samples, visual quality of fresh-cut pineapples had the same rating to whole pineapples bought from corresponding markets.

The appearance of the product usually determines whether a product is accepted or rejected. Therefore, this is one of the most critical quality attributes. By processing the fruits to fresh cuts, mechanical injury is being applied which can inflict and enhance quality deterioration especially the appearance. Internal and external factors affect the wound response of fruits. These include species, cultivar, maturity, storage/ processing temperature, cutting protocols, $\mathrm{CO}_{2}$ and $\mathrm{O}_{2}$ levels, and water vapor pressure (Kader, 2002).

\subsubsection{Color}

Differences on color $\left(L^{*}, a^{*}, b^{*}\right)$ were also noted on fresh cut samples and whole fruits. The Hunter $L^{*}, a^{*}$, $\mathrm{b}^{*}$ color space is organized in a cube form. The $\mathrm{L}^{*}$ axis runs from the top to bottom. The maximum for $\mathrm{L}^{*}$ is 100 and the minimum is 0 (black). Positive $\mathrm{a}^{*}$ is red and negative $a^{*}$ is green. Positive $b^{*}$ is yellow and negative $b^{*}$ is blue (Technical Services Department Hunter Associates Laboratory Inc., 2001). Color is derived from the natural pigments in fruits, many of which change as the plant proceeds through maturation and ripening. An important issue in fresh-cut fruit processing is the control of discoloration or browning on cut surfaces. Enzymatic browning is one of the most limiting factors on the shelf life of fresh-cut fruits. During the preparation stages, the fruit is subjected to operations where cells are broken, causing enzymes to be liberated from tissues and put in contact with their substrates (Laminkara, 2002). Also, the color of the fruits plays an important role in consumer perception. According to Walker (n.d.), consumers rely on the color to determine the level of ripeness and/or freshness. When a food color is off, the brain tells the consumers that it tastes different without physically tasting the food.

\subsubsection{Vitamin $C$}

Vitamin $\mathrm{C}$ of fresh cut watermelons ranged from 4.04-7.59 mg/100 g while whole watermelons ranged from 9.41-10.38 mg/100 g. Vitamin C content of freshcut pineapples ranged from $4.9-7.05 \mathrm{mg} / 100 \mathrm{~g}$ and whole pineapples ranged from $9.05-11.40 \mathrm{mg} / 100 \mathrm{~g}$. Lower vitamin $\mathrm{C}$ contents were obtained from fresh cut samples than those of the whole samples. Also, lower vitamin C contents were obtained on samples from wet markets than those on samples from supermarkets. Vitamin C is most sensitive to destruction when the commodity is subjected to adverse handling and storage conditions. Losses are enhanced by extended storage, exposure to light, higher temperatures, low relative humidity, 
physical damage, and chilling injury (Lee and Kader, 2000). Generally, fruits and vegetables show a gradual decrease in vitamin $\mathrm{C}$ content as the storage temperature or duration increases (Adisa, 1986). Comparing the conditions in the supermarkets and wet markets, wet markets have higher temperatures and light exposure. The fruits are also more prone to physical damage due to poor handling practices compared with supermarkets. These may have caused lower vitamin $\mathrm{C}$ contents in fresh-cut fruits from the wet markets.

\subsubsection{Titratable acidity}

For titratable acidity (TA), \%TA of fresh cut watermelons ranged from $0.053-13 \%$ while that of whole watermelons ranged from $0.61-0.74 \%$. TA of fresh cut pineapples ranged from $0.071-0.41 \%$ and that of whole pineapples ranged from $0.19-0.29 \%$. No trend on titratable acidity was observed on fresh cut samples and whole samples. This is due to the fact that watermelon and pineapple are considered as non-climacteric fruits (Salman-Minkov et al., 2008) and acid content does not increase further after harvesting. There will not be significant changes in the amount of acids even after fresh-cut processing of the fruits, thus the values obtained were close to each other.

\section{$3.1 .5 \mathrm{pH}$}

The $\mathrm{pH}$ of fresh cut watermelons ranged from 5.195.80 while that of whole watermelons ranged from 5.656.04. The $\mathrm{pH}$ of fresh cut pineapples ranged from 3.674.05 while that of whole pineapples ranged from 3.823.97. Watermelon and pineapple, being non-climacteric fruits, ripen only while still attached to the parent plant. Generally, the $\mathrm{pH}$ value of fruit juice remains fairly constant during ripening and rises during senescence. The same as that of TA, $\mathrm{pH}$ also remained almost constant even after fresh-cut processing. The type of market likewise did not affect $\mathrm{pH}$.

\subsubsection{Total soluble solids}

TSS of fresh cut watermelons ranged from $6.3-8.2^{\circ}$ Brix while that of whole watermelons ranged from 6.89. $0^{\circ}$ Brix. TSS of fresh cut pineapples ranged from 12.9$15.6^{\circ}$ Brix while that of whole pineapples ranged from 12.2-14. $3^{\circ}$ Brix. Significance difference in TSS of whole watermelons compared with the fresh-cut samples. Total soluble solids reflect the amount of sugars present. These sugars are consumed during respiration. Upon slicing of fruits, respiration is enhanced due to the disruption of cells, consuming more of the sugars. Thus, higher TSS values were observed.
3.2 Microbiological quality of fresh-cut watermelon and fresh-cut pineapple

Microbiological quality evaluation was done, and the values were compared with the microbiological limits from the European Commission Regulation 2073/2005 on microbiological criteria in foodstuff (Table 5). Above these guidelines, the fresh-cut produce is considered not safe. Results of microbial analyses are shown in Table 3 for watermelon and Table 4 for pineapple.

Table 5. Overview of Microbiological Guidelines for FreshCut Fruits (CFU/g)

\begin{tabular}{cccc}
\hline Parameter & $*$ Target & $* *$ Tolerance & $\begin{array}{c}* * * \text { Best before } \\
\text { date }\end{array}$ \\
\hline Total Plate Count & 105 & 106 & 107 \\
Yeast and Moulds & 103 & 104 & 105 \\
Coliforms & 102 & 102 & 103 \\
Salmonella & Absent $/ 25 \mathrm{~g}$ & Absent $/ 25 \mathrm{~g}$ & Absent $/ 25 \mathrm{~g}$ \\
Escherichia coli & Absent/25 g & Absent $/ 25 \mathrm{~g}$ & Absent/25 g \\
\hline
\end{tabular}

*Target is the guideline for the production day, in the best conditions produced.

** Tolerance is the maximum guideline for the production day.

$* * *$ Best before date is the end of the shelf-life, and above these guidelines, notable spoilage will occur.

(Source: European Commission Regulation 2073/2005 on microbiological criteria in foodstuff, 2005)

\subsubsection{Total plate count}

The total plate count (TPC) of fresh cut watermelons had average values from $4.5 \times 10^{5}$ to $2.4 \times 10^{7} \mathrm{CFU} / \mathrm{g}$ (Table 3). One out of the four samples had counts higher than the maximum guideline of TPC for the production day which is $10^{6} \mathrm{CFU} / \mathrm{g}$. Fresh cut watermelons from wet market 2 were shown to have the highest total plate count $\left(2.5 \times 10^{7} \mathrm{CFU} / \mathrm{g}\right)$ while fresh cut watermelons from wet market 1 were shown to have the lowest TPC of an average of $4.5 \times 10^{5} \mathrm{CFU} / \mathrm{g}$. The fresh cut watermelons from the two supermarkets had average values which are within the acceptable level. For the fresh cut pineapple (Table 4), its TPC had average values from $8.2 \times 10^{6}$ to $1.6 \times 10^{7} \mathrm{CFU} / \mathrm{g}$. Two out of the four samples had counts higher than the maximum guideline of TPC for the production day. Fresh cut pineapples from supermarket 1 and wet market 2 were shown to have the highest total plate count $\left(1.6 \times 10^{7} \mathrm{CFU} / \mathrm{g}\right)$ while fresh cut pineapples from supermarket 2 were shown to have the lowest TPC $8.2 \times 10^{6} \mathrm{CFU} / \mathrm{g}$.

The total viable count is the total number of bacteria able to grow in an aerobic environment in a moderate temperature. Total plate counts can provide useful information about the general quality and remaining shelf life of the food, and highlight potential problems of storage and handling since production. The TPC in ready -to-eat foods will depend initially on the type and 
Table 3. Microbial counts from of fresh-cut watermelons obtained from different supermarkets and wet markets in Imus, Cavite

\begin{tabular}{cccccc}
\hline$* *$ Code & Total plate count (CFU/g) & Yeast and molds (CFU/g) & Total coliforms (CFU/g) & Escherichia coli & Salmonella \\
\hline SM1P1 & $1.5 \times 10^{6}$ & $4.2 \times 10^{4}$ & $* 2.1 \times 10^{4}$ & $(-)$ & $(+)$ \\
SM1P2 & $4.7 \times 10^{5}$ & $1.0 \times 10^{2}$ & $* 1.8 \times 10^{4}$ & $(-)$ & $(+)$ \\
SM1P3 & $3.5 \times 10^{5}$ & $3.1 \times 10^{2}$ & $* 6.4 \times 10^{3}$ & $(-)$ & $(-)$ \\
SM2P1 & $2.1 \times 10^{6}$ & $5.6 \times 10^{2}$ & $* 1.2 \times 10^{5}$ & $(-)$ & $(-)$ \\
SM2P2 & $3.4 \times 10^{4}$ & $3.4 \times 10^{3}$ & $* 2.5 \times 10^{4}$ & $(-)$ & $(-)$ \\
SM2P3 & $2.4 \times 10^{6}$ & $2.0 \times 10^{2}$ & $* 1.8 \times 10^{4}$ & $(-)$ & $(-)$ \\
WM1P1 & $4.3 \times 10^{5}$ & $<1 \times 10$ est. & $* 1.5 \times 10^{5}$ & $(-)$ & $(-)$ \\
WM1P2 & $1.5 \times 10^{5}$ & $<1 \times 10$ est. & $* 3.4 \times 10^{3}$ & $(-)$ & $(-)$ \\
WM1P3 & $7.7 \times 10^{5}$ & $<1 \times 10$ est. & $(-)$ \\
WM2P1 & $* 1.9 \times 10^{7}$ & $<1 \times 10$ est. & $* 3.2 \times 10^{3}$ & $(-)$ & $(-)$ \\
WM2P2 & $* 2.5 \times 10^{7}$ & $<1 \times 10$ est. & $* 3.6 \times 10^{3}$ & $(-)$ & $(-)$ \\
WM2P1 & $* 2.5 \times 10^{7}$ & $<1 \times 10$ est. & $* 3.4 \times 10^{3}$ & $(-)$ & $(+)$
\end{tabular}

*Exceeded maximum count/tolerance level for the production day

**Code: SM1 - Supermarket 1; SM2- Supermarket 2; WM1 - Wet market 1; and WM2 - Wet market 2.

Table 4. Microbial counts from fresh-cut pineapples obtained from different supermarkets and wet markets in Imus, Cavite

\begin{tabular}{|c|c|c|c|c|c|}
\hline Code** & Total plate count (CFU/g) & Yeasts and molds (CFU/g) & Total coliforms (CFU/g) & Escherichia coli & Salmonella \\
\hline SM1P1 & $* 1.8 \times 10^{7}$ & $* 2.4 \times 10^{5}$ & $* 1.4 \times 10^{4}$ & $(-)$ & $(-)$ \\
\hline SM1P2 & $* 1.9 \times 10^{7}$ & $* 1.8 \times 10^{5}$ & $* 1.1 \times 10^{4}$ & $(-)$ & $(-)$ \\
\hline SM1P3 & $* 1.1 \times 10^{7}$ & $* 2.0 \times 10^{5}$ & $* 1.3 \times 10^{4}$ & $(-)$ & $(-)$ \\
\hline SM2P1 & $* 1.1 \times 10^{7}$ & $* 1.7 \times 10^{5}$ & $* 5.0 \times 10^{3}$ & $(-)$ & $(+)$ \\
\hline SM2P2 & $6.5 \times 10^{6}$ & $6.0 \times 10^{4}$ & $* 1.5 \times 10^{4}$ & $(-)$ & $(-)$ \\
\hline SM2P3 & $7.0 \times 10^{6}$ & $* 1.2 \times 10^{5}$ & $* 3.7 \times 10^{3}$ & $(-)$ & $(-)$ \\
\hline WM1P1 & $* 1.1 \times 10^{7}$ & $* 1.4 \times 10^{6}$ & $* 1.2 \times 10^{4}$ & $(-)$ & $(-)$ \\
\hline WM1P2 & $2.9 \times 10^{6}$ & $* 2.4 \times 10^{6}$ & $* 1.6 \times 10^{4}$ & $(-)$ & $(+)$ \\
\hline WM1P3 & $* 1.5 \times 10^{7}$ & $* 2.4 \times 10^{6}$ & $* 1.7 \times 10^{3}$ & $(-)$ & $(-)$ \\
\hline WM2P1 & $2.8 \times 10^{6}$ & $4.9 \times 10^{4}$ & $4.9 \times 10^{2}$ & $(-)$ & $(+)$ \\
\hline WM2P2 & $1.6 \times 10^{6}$ & $* 2.1 \times 10^{5}$ & $6.2 \times 10^{2}$ & $(-)$ & $(+)$ \\
\hline WM2P1 & $* 2.8 \times 10^{7}$ & $* 1.1 \times 10^{5}$ & $8.8 \times 10^{2}$ & $(-)$ & $(-)$ \\
\hline
\end{tabular}

*Exceeded maximum count/tolerance level for the production day

**Code: SM1 - Supermarket 1; SM2- Supermarket 2; WM1 - Wet market 1; and WM2 - Wet market 2.

duration of processing that the food has received during production. Thereafter the level will depend on how it is handled and stored (Health Protection Agency, 2009).

\subsubsection{Yeasts and molds count}

Yeasts and molds of fresh-cut watermelons from wet markets had average counts as low as $<1 \times 10$ est. While the average counts of fresh-cut watermelon from supermarket 1 and 2 were $1.4 \times 10^{3}$ and $1.4 \times 10^{4} \mathrm{CFU} / \mathrm{g}$, respectively. For the fresh-cut pineapple, its yeasts and molds had values from $1.2 \times 10^{5}$ to $2.1 \times 10^{6} \mathrm{CFU} / \mathrm{g}$. Fresh cut pineapples from wet market 1 shown to have the highest yeasts and molds $\left(2.1 \times 10^{6} \mathrm{CFU} / \mathrm{g}\right)$ while fresh cut pineapples from supermarket 2 and wet market 2 shown to have the lowest yeasts and molds $\left(1.2 \times 10^{5}\right.$ $\mathrm{CFU} / \mathrm{g})$. All samples of fresh-cut pineapples exceeded the maximum allowable limit for yeasts and molds for the production day.
Both yeasts and molds cause various degrees of deterioration and decomposition of foods. It can invade and grow on virtually any type of food at any time. According to CondaLab (2016), yeasts and molds are particularly problematic in plants producing high sugar/ low water activity/low $\mathrm{pH}$ products. Fresh-cut pineapple samples exceeded the maximum tolerable count for the production day. This may be attributed to the high sugar and low $\mathrm{pH}$ s of pineapple which was favorable for the growth of yeasts and molds. Also, contamination of the fresh-cut fruits may be obtained from the tools, utensils and building surfaces. According to Texas A\&M Agrilife Extension (2016), yeasts and molds grow on most foods, on equipment, and building surfaces where there are small amounts of nutrient and moisture.

\subsubsection{Total coliform count}

The total coliform count of fresh cut watermelons had values from $3.4 \times 10^{3}$ to $5.8 \times 10^{4} \mathrm{CFU} / \mathrm{g}$. Fresh-cut 
watermelons from wet market 1 were shown to have the highest total coliform count $\left(5.8 \times 10^{4} \mathrm{CFU} / \mathrm{g}\right)$ while fresh cut watermelons from wet market 2 shown to have the lowest total coliform count $\left(3.4 \times 10^{3} \mathrm{CFU} / \mathrm{g}\right)$. For the fresh cut pineapple, its total coliform count had values from $6.6 \times 10^{2}$ to $1.3 \times 10^{4} \mathrm{CFU} / \mathrm{g}$. Fresh cut pineapples from supermarket 1 had the highest total coliform count $\left(1.3 \times 10^{4} \mathrm{CFU} / \mathrm{g}\right)$ while fresh cut pineapples from wet market 2 had the lowest total coliform count of $6.6 \times 10^{2} \mathrm{CFU} / \mathrm{g}$. All samples, except for fresh cut pineapples from wet market 2 , had exceeded the maximum allowable limit for total coliforms for the production day which is $10^{2} \mathrm{CFU} / \mathrm{g}$. Total coliform bacteria are commonly found in the environment (e.g., soil or vegetation) and are generally harmless. The coliform count is a hygienic indicator and high level of coliform counts generally indicates unsanitary condition or poor hygiene practices during or after food production (Center for Food Safety, 2013). The results on the total coliforms indicate that fresh cuts fruits were prepared in an unsanitary condition and/or processor had poor hygiene practices during or after food production.

\subsubsection{Escherichia coli (E. coli)}

All fresh cut watermelons and fresh cut pineapples were shown to be negative in E. coli. E. coli is an organism that is part of the normal microflora of the intestinal tract of humans and warm-blooded animals. As such, their presence in ready-to-eat fruits can be an indication of poor hygiene and sanitation (NSW Food Authority, 2009). E. coli is a commonly used fecal indicator organism. Its presence in food generally indicates direct or indirect fecal contamination. A substantial number of $E$. coli in food suggests a general lack of cleanliness in handling and improper storage (Center for Food Safety, 2014).

\subsubsection{Salmonella}

Samples of fresh cut watermelons (2 out of 3 samples from supermarket 1, 1 out of 3 samples from wet market 1 , and 1 out of 3 samples from wet market 2) were shown to be positive for Salmonella. Samples of fresh cut pineapples ( 1 out of 3 samples from supermarket 2, 1 out of 3 samples from wet market 1, and 2 out of 3 samples from wet market 2) were shown to be positive for Salmonella.

Salmonella species are enteric bacteria and can be found in the intestinal tract of animals. As such, Salmonella can frequently be isolated from raw foods of animal origin. Environmental contamination can also result in Salmonella being present in a wide variety of foods. The presence of Salmonella in ready-to-eat foods may be a result of poor handling practices and cross contamination. (NSW Food Authority, 2009). Food may be contaminated by Salmonella in animal feces and cross -contamination may occur during further processing and preparation. Many foods, particularly those of animal origin and those subject to sewage pollution, have been identified as vehicles for transmitting these pathogens (ICMSF, 1996). Presence of Salmonella in fresh-cut watermelons and pineapples could indicate poor handling practices and cross-contamination from tools and utensils. Sewage near the sampling points in wet markets may also be attributed to the Salmonella contamination of the samples.

Contamination sources of fresh-cut fruits and vegetables include raw materials and contact with processing equipment. The microorganisms that exist on the surfaces of raw, whole produce appear to be the major source of microbial contamination and consequent spoilage of fresh-cut fruits. Fresh-cut products can also be contaminated by spoilage microorganisms through contact by people or equipment during processing possibly by air during processing and packaging steps, especially in facilities that have been used for produce processing over an extended period of time (Sperber and Doyle, 2009).

From the obtained microbiological analyses results, no trend of counts was observed between supermarkets and wet markets. Results showed that in either sample obtained from supermarkets, or from wet markets, microbial growth exceeds the tolerable limit. This implies unsanitary preparation of fresh-cuts in both market types. Even though the conditions in both markets differ in terms of the temperature, lighting, humidity and other factors, the microbiological evaluation reflects that samples do not differ in both markets. This implies that the sanitation of the preparation of the fresh-cut fruits in both markets does not differ. Thus, microbial safety of fresh-cut fruits is highly dependent on the manner of their preparation and not much on the storage conditions.

\section{Conclusion}

Evaluation of physico-chemical qualities of fresh-cut samples showed that samples from the wet market have poorer quality than those from the supermarket. Comparing fresh-cuts from intact fruits, there was deterioration in the nutritional quality particularly vitamin $\mathrm{C}$ when the fruits were processed into fresh cuts. In terms of microbial quality and safety, overall, the samples from wet markets and supermarkets have almost the same levels of microbial loads. The same is true with their levels of the pathogens E. coli and Salmonella. Thus, fresh-cut fruits from both markets do not differ in 
microbial quality but only differ in their physicochemical properties.

\section{Conflict of Interest}

There is no conflict of interest in this study.

\section{Acknowledgments}

The authors would like to thank the UP System Emerging Interdisciplinary Research (EIDR) Program (OVPAA-EIDR P-19-612-102) for providing funds for this research. Additional funds were also given by the Department of Science and Technology Accelerated Science and Technology Human Resource Development Program (DOST-ASTHRDP).

\section{References}

Adisa, V.A. (1986). The influence of molds and some storage factors on the ascorbic acid content of orange and pineapple fruits. Food Chemistry, 22, 139-146. https://doi.org/10.1016/0308-8146(86)90031-2

Ahvenainen, R. (1996). New approaches in improving the shelf life of minimally processed fruit and vegetables. Trends in Food Science and Technology, 7(6), 179-187. https://doi.org/10.1016/0924-2244 (96)10022-4

Brody, A.L., Zhuang, H. and Han, J.H. (2011). Modified atmosphere packaging for fresh-cut fruits and vegetables. Iowa: Blackwell Publishing Ltd. https:// doi.org/10.1002/9780470959145

Center for Food Safety. (2013). Coliforms: Traditional hygienic indicator. http://www.cfs.gov.hk/english/ whatsnew/whatsnew_fst/

whatsnew_fst_Coliforms_Traditional_Hygienic_Indi cator.html

Center for Food Safety. (2014). Microbiological guidelines for food: For ready to eat food in general and specific food items. http://www.cfs.gov.hk/ english/food_leg/files/

food_leg_Microbiological_Guidelines_for_Food_e

Chien, P.J, Sheu, F. and Yang, F.H. (2007). Effects of edible chitosan coating on quality and shelf life of sliced mango fruit. Journal of Food Engineering, 78 (1), 225-229. https://doi.org/10.1016/ j.jfoodeng.2005.09.022

Condalab. (2016). Yeast and molds in food. http:// www.condalab.com $/$ pdf $/ 01$.Yeast $\% 20$ And $\%$ 20Mold\%20in\%20Food_small.pdf

European Commission (2005). Microbiological criteria for foodstuffs. No. 2073/2005. Retrieved from website: https://publications.europa.eu/en/ publication-detail/-/publication/d62db802-56e9-4052

\section{-888f-ff5def2fa0f2/language-e}

Health Protection Agency. (2009). Guidelines for Assessing the microbiological safety of ready-to-eat foods. London: Health Protection Agency.

International Commission on microbiological specifications for foods (ICMSF). (1996). Salmonellae. In Micro-organisms in Foods 5: Characteristics of Microbial Pathogens, p. 217-264. London: Chapman and Hall.

James, I.F. and Kuipers, B. (2003). Preservation of fruit and vegetables. Agrodok 3. Wageningen: Agromisa Foundation.

James, J.B. and Ngarmsak, T. (2010). Processing of fresh -cut tropical fruits and vegetables: A technical guide. Bangkok: Food and Agriculture Organization of the United Nations.

Kader, A.A. (Eds.) (2001). Postharvest Technology of Horticultural Crops, p. 5-30. USA: University of California Division of Agriculture and Natural Resources.

Kim, J.G. (2007). Fresh-cut market potential and challenges in Far-East Asia. Acta Horticulturae. 746, 53-60. https://doi.org/10.17660/

ActaHortic.2007.746.2

Kocheri, S. (2015). Consumption of Fruits and Vegetables Global and Asian Perspective. Hort Asia $2015,17^{\text {th }}-19^{\text {th }}$ March 2015, Thailand: Horti Asia.

Lamikanra, O. (2002). Fresh-cut fruits and vegetables. Science, technology and market. Boca Raton, FL: CRC Press. https://doi.org/10.1201/9781420031874

Lee, S.K. and Kader, A.A. (2000). Preharvest and postharvest factors influencing vitamin $\mathrm{C}$ content of horticultural crops. Postharvest Biology and Technology, 20(3), 207-220. https://doi.org/10.1016/ S0925-5214(00)00133-2

NSW Food Authority (NSWFA). (2009). Microbiological quality guide for ready-to-eat foods: A guide to interpreting microbiological results. Retrieved from website: www.foodauthority.nsw.gov.au

Salman-Minkov, A., Levi, A., Wolf, S. and Trebitsh, T. (2008). ACC synthase genes are polymorphic in watermelon (Citrullus spp.) and differentially expressed in flowers and in response to auxin and gibberellin. Plant Cell Physiology, 49(5), 740-750. https://doi.org/10.1093/pcp/pen045

Sa-Nguanpuag, K., Kanlayanarat, S. and Tanprasert, K. (2007). Trends of fresh-cut produce in Thai retail markets for identification of packaging for shredded green papaya. Acta Horticulturae, 746, 481-483. https://doi.org/10.17660/ActaHortic.2007.746.60

Sperber, W.H. and Doyle, M.P. (2009). Compendium of 
the Microbiological Spoilage of Foods and Beverages, Food Microbiology and Food Safety. USA: Springer Science+Business Media, LLC. https://doi.org/10.1007/978-1-4419-0826-1

Technical Services Department Hunter Associates Laboratory Inc. (2001). Application Note, vol. 13, p. 1-4. USA; Hunter Lab Color Scale

Texas A\&M Agrilife Extension. (2016). Introduction to the microbiology of foods: The microorganisms. Retrieved from website: http://aggiehorticulture.tamu.edu/food-technology/foodprocessing-entrepreneurs/microbiology-of-food/

Ukuku, D.O. and Fett, W. (2002). Behavior of Listeria monocytogenes inoculated on cantaloupe surfaces and efficacy of washing treatments to reduce transfer from rind to fresh-cut pieces. Journal of Food Protection, 65(6), 924-930. https:// doi.org/10.4315/0362-028X-65.6.924

Varoquaux, P. and Maxollier, J. (2002). Overview of the European fresh-cut produce industry. In Lamikanra, O. (ed.). Fresh-cut fruits and vegetables: Science, technology and market. Boca Paton, FL: CRC Press.

Walker, L. (n.d.) The influence of color on taste perception. Retrieved from website: https:// www.fona.com/sites/default/files/The $\% 20$ Effects $\%$ 20of\%20Food\%20Coloring.pdf

Woteki, C.E. and Kineman, B.E. (2003). Challenges and approaches to reducing foodborne illness. Annual Review of Nutrition, 23, 315-44. https:// doi.org/10.1146/annurev.nutr.23.011702.073327 